\title{
Some peculiarities of excavation of three flat seams strata using draglines
}

\author{
Andrew Fedotov ${ }^{1, *}$, Yaroslav Litvin ${ }^{2}$, Anton Stukan ${ }^{3}$, and Martin Kapko ${ }^{4}$ \\ ${ }^{1}$ T.F. Gorbachev Kuzbass State Technical University, Open Pit Mining Department, \\ 650000 Kemerovo, 28 Vesennyaya st., Russian Federation \\ 2 Branch of the JSC «Kuzbassrazrezugol» Mokhovsky Open Pit Mine, Mokhovo \\ settlement, Belovsky district, 652661, Kemerovo region, Russia \\ ${ }^{3}$ Mezhdurechensk Branch of T.F. Gorbachev Kuzbass State Technical University, 652877 \\ Mezhdurechensk, 36 Stroitelei av., Russian Federation \\ 4 Technical University in Kosice, Faculty of Mining, Ecology, Process Control and \\ Geotechnologies, Letná 9, 04200 Kosice, Slovak Republic
}

\begin{abstract}
One of the methods of increasing the efficiency of dragline operation is to optimize their work when mining the end sections of the cuts. This is especially important when the length of the work front is relatively short. With mining operations going deeper, and the complication of mining and geological conditions of bedding, it often becomes necessary to mine shorter face sections. However, as a rule, design bureaus do not take into account and do not visualize excavation of end sections, because these are, in fact, special cases of standard excavation schemes. Nevertheless, it significantly complicates the organization of mining operations due to the need to create routes for draglines to ascend and descend to the dump tiers. Scientific literature does not pay enough attention to this issue due to its complexity and the need for a full-scale field experiment, which in modern conditions is often very problematic. This article establishes the relevance of the above-mentioned issue and identifies directions for further research.
\end{abstract}

\section{Introduction}

In the schemes of excavation with dumping of three-tier dumps, the organization of the dragline operation is complicated due to the need to perform two additional working moves due to dumping of the third tier and the associated creation of paths of ascent (descent) of the excavator when it changes the standing level.

In the mining and geological conditions of the Krasnogorsky open pit, it is advisable to use just such a scheme of work: with dumping of the three-tier internal dump. Below is a brief description of the mining and technical conditions at the site.

Overburden rocks above seam XXIV are mined by horizontal benches. Depending on their thickness, the overburden partings are mined by both horizontal benches and inclined

*Corresponding author: fedotovaa@mail.ru 
layers. The parameters of the main mining equipment adopted for overburden mining, the use of drilling and blasting operations to prepare the overburden for excavation, the physical and mechanical characteristics of the rocks, and the current stripping pattern predetermined the height of the horizontal benches to be $15 \mathrm{~m}$. To reduce the volume of road construction works on the benches, the width of cut in the solid rock is $40.0 \mathrm{~m}$, the value of the working and stable angle of the benches slopes is 75 and 60 degrees, respectively. It is allowed to work double overburden benches $30,0 \mathrm{~m}$ high in layers. Benches cutting is carried out by rope shovels with loading in quarry haul trucks.

\section{Transportless mining technology}

A considerable number of works are devoted to the study of the parameters of transportless technology, in particular [1-15], where such issues as opening and excavation of stockpiled reserves, various cases for specific conditions, issues of drilling and blasting preparation of rock mass in the transportless zone, perspectives of technology using draglines and other issues are discussed. The technology of open-pit mining in the southern Kuzbass is not well-studied [16-24]. Below is a description and procedure for mining operations in the transportless zone of Krasnogorsky open-pit mine.

On the eastern flank of the Kiyzaksky 9 section, overburden above the XXIV seam and partings of seams XXIV-XXXI are mined using the transport system. Overburden rocks above seam XXVII are mined by horizontal benches $15.0 \mathrm{~m}$ high. The working angle of the bench slope is $75^{\circ}$, and the stable angle is $60^{\circ}$. The width of the cut in the bedrock is 40.0 $\mathrm{m}$. The width of the working site is $62.0 \mathrm{~m}$; the non-working site is $22.0 \mathrm{~m}$. The parting of layers XXVII-XXXI are mined by inclined layers, the height of which is equal to the thickness of the partings. In order to provide through passage to the coal storages of the railway station, width of the working site on the bottom of seam XXIX-XXX is increased to $100.0 \mathrm{~m}$. Partings of XXX-XXXa and XXXa-XXXI seams are mined by rope shovels with loading in dump trucks and further dumping of overburden into the mined-out area of the transportless mining system. The parting of formations XXXI-XXXII-XXXIII is mined by dragline excavators ESh 15.90 (ESh 20.90) with placing overburden in the mined-out area. The profile re-excavation ratio, defined by the technological schemes of mining works in the zone of the transportless mining system, is 0.70 . At the same time, in the flank areas additional re-excavation of overburden rocks is required with their placement in the third tier of the internal dump. These works are carried out in two stages - in the first stage the dragline re-excavates flank volume of overburden, distributing them on a front at the rate of $630 \mathrm{~m}^{3}$ on 1 running meter of a front; in the second stage flank volumes of rocks together with volume of the basic cut are placed in the three-tier internal dump. Taking into account additional volumes of re-excavation in the flank areas, during arrangement of excavator routes, ramps, as well as taking into account the actual data obtained from the open pit, the total re-excavation ratio in the eastern flank of Kiyzaksky 9 section was taken to be 2.0. The XXXII seam is opening with the first dragline pass. At the same time, the dragline is positioned on the blasted rock mass, forming a route at the level of the XXXII seam bottom. Overburden rocks between seams XXXI-XXXII are placed in the first tier of the internal dump (pre-dump). At the level of the XXXII seam bottom in the mined-out area a horizontal site (quarry road, see Fig. 1-3) is left for the passage of trucks when working out the XXXII layer and making it possible to drill the parting of the XXXII-XXXIII seam immediately following the XXXII seam excavation. The second pass of the dragline opens the XXXIII seam. The excavator's route is located at the level of the first tier of the internal dump. Rocks between seams XXXII-XXXIII are placed in the remaining capacity of the first tier and in the second tier of the internal dump. During the third pass the draglines, 
being at the level of the second tier, re-excavate part of the rock into the third tier, thus finally forming the internal dump with the general angle of slope of $28^{\circ}$.
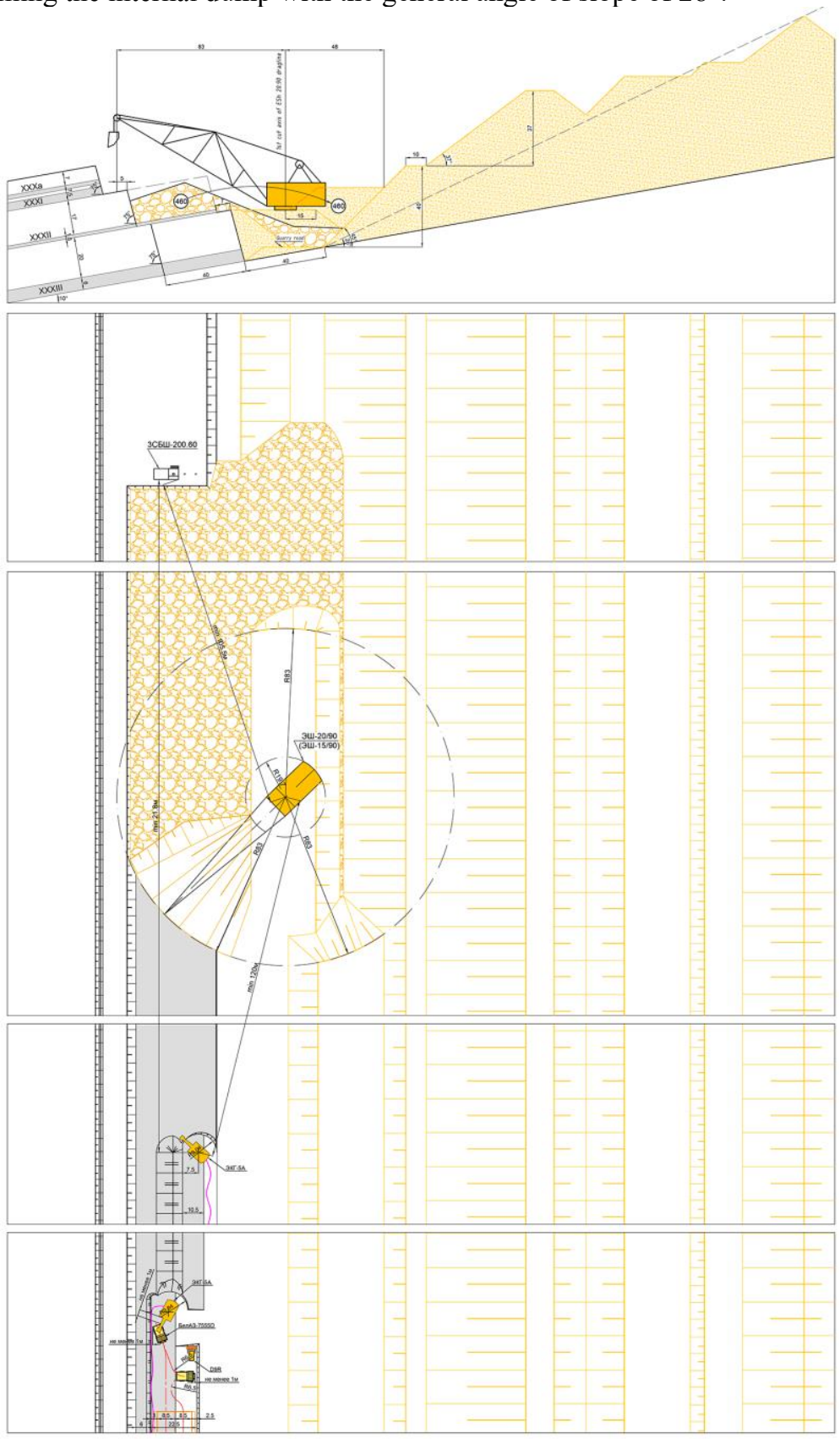

Fig. 1. Excavation of the upper parting ( $1^{\text {st }}$ cut $)$ 


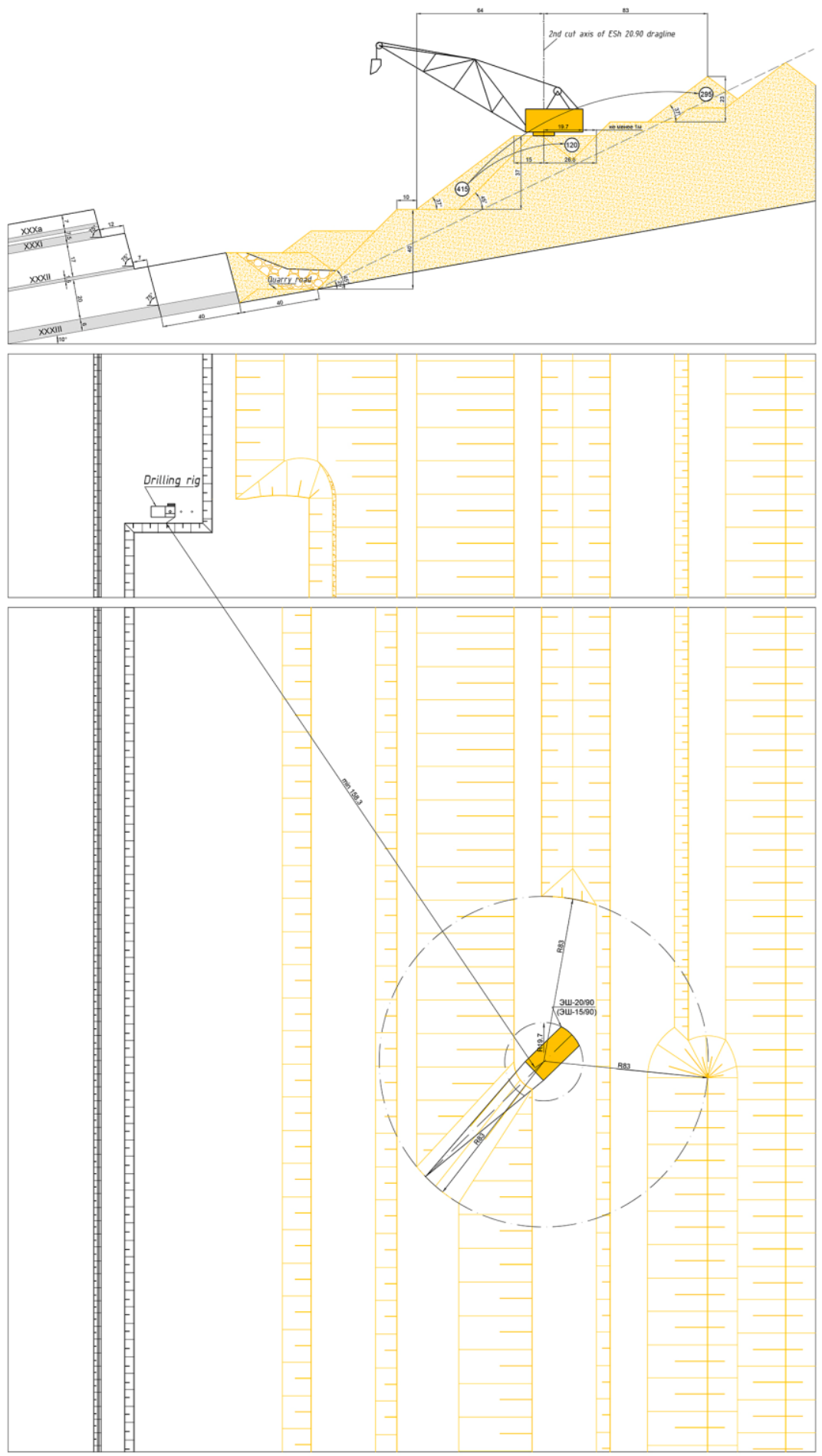

Fig. 2. Overburden removing from $2^{\text {nd }}$ to $3^{\text {rd }}$ internal dump tier (preparing an additional capacity: $2^{\text {nd }}$ cut) 

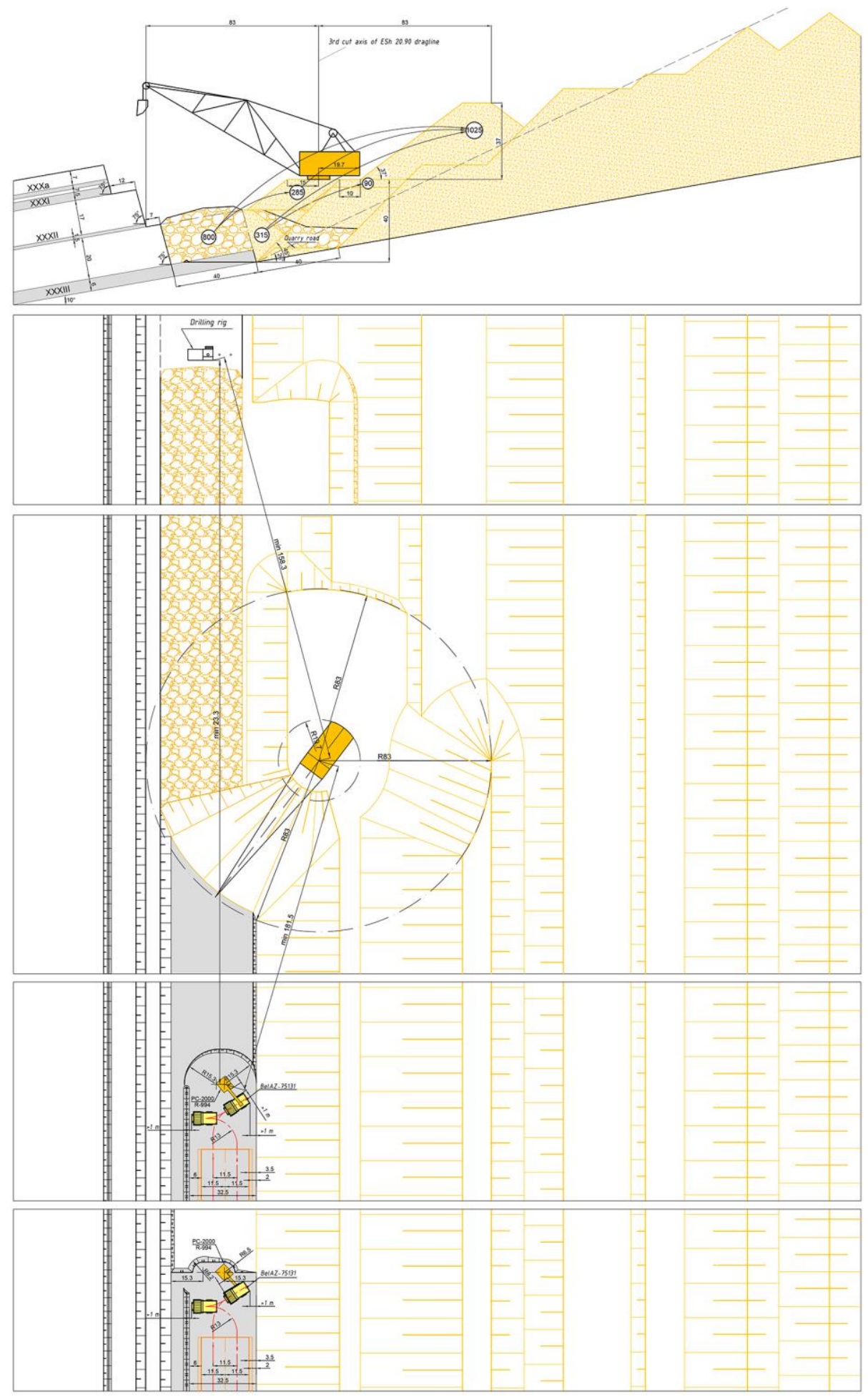

Fig. 3. Excavation of the lower parting ( $3^{\text {rd }}$ cut $)$ 


\section{Conclusions}

As follows from the presented technological schemes, only the operation of the dragline in the mine workings profile without taking into account the peculiarities of excavating the end parts of the cuts is considered in detail. In our opinion, the first-priority directions in this matter are:

1) studying the organization of mining operations during the dragline's transition along the dump tiers;

2) determination of the possibility of more efficient excavation of rock volumes from the end parts of the cuts;

3) calculation of rock excavation volumes in case of change of mining-geological and mining-technical parameters of the site;

4) searching for the most rational method of excavation of the end parts of cuts.

\section{References}

1. V.L. Martyanov, J Mining Geotech Eng, 1:35 (2018) DOI: 10.26730/2618-7434-2018$1-35-41$

2. M. Tyulenev, S. Markov, M. Cehlar, S. Zhironkin, M. Gasanov, Acta Montanistica Slovaca, 23:4, 368 (2018)

3. M.M. Bereznyak, A.V. Kalinin, V.G. Pronoza, Soviet Mining, 6:6, 638 (1970)

4. I. Vukotic, V. Kecojevic, W. Zhang, Q. Cai, S. Chen, Int J Mining Sci Tech, 23:6, 901 (2013)

5. S. Markov, J. Janočko, M. Tyulenev, Y. Litvin, E3S Web of Conferences, 105, 01021 (2019)

6. M. Tyulenev, S. Markov, A. Palamarchuk, T. Gvozdkova, J Mining Geotech Eng, 3:10, 18 (2020)

7. A.V. Vaneev, J Mining Geotech Eng, 2, 13 (2018)

8. M. Mohammadi, P. Rai, S. Gupta, Acta Montranistica Slovaca, 21:1, 1 (2016)

9. M. Vaněk, G.F. Valverde, I. Černý, V. Hudeček, Acta Montanistica Slovaca, 25:2, 170 (2020)

10. M. Tyulenev, S. Zhironkin, E. Tyuleneva, A. Abay, S. Anyona, M. Hellmer, Coal International, 265:3, 30 (2017)

11. H. Mirabediny, A dragline simulation model for strip mine design and development (University of Wollongong, Wollongong, 1998)

12. M. Tyulenev, Yu. Lesin, E. Tyuleneva, E. Murko, E3S Web of Conf., 15, 02003 (2017)

13. V.F. Kolesnikov, J. Janočko, J Mining Geotech Eng, 2:9, 42 (2020)

14. S. Markov, M. Tyulenev, O. Litvin, E. Tyuleneva, E3S Web of Conf., 15, 01011 (2017)

15. P. Rai, Indian J Eng Material Sci, 11, 493 (2004)

16. M. Tyulenev, S. Markov, E. Makridin, Yu. Lesin, V. Gogolin, E3S Web of Conf., 105, 02022 (2019)

17. M. Andrejiova, A. Grincova, D. Marasova, P. Grendel, Acta Montanistica Slovaca, 20:1, 26 (2015)

18. S. Markov, V. Martyanov, E. Preis, A. Abay, E3S Web of Conf., 21, 01021 (2017) 
19. A. Strelnikov, S. Markov, L. Rattmann, D. Weber, E3S Web of Conf., 41, 01003 (2018) DOI: $10.1051 / \mathrm{e} 3$ sconf $/ 20184101003$

20. Y. Lesin, V. Gogolin, E. Murko, S. Markov, J. Kretschmann, E3S Web of Conf., 41, 01039 (2018)

21. M. Grujic, D. Malindzak, D. Marasova, Tehnicki Vjesnik, 18:3, 453 (2011)

22. M.A. Tyulenev, S.O. Markov, M.A. Gasanov, S.A. Zhironkin, Geotech Geol Eng, 36:5, 2789 (2018)

23. K. Drebenshtedt, V.I. Golik, Yu.V. Dmitrak, Sustainable development of mountain territories, 10:1, 125 (2018)

24. A. Khoreshok, K. Ananiev, A. Ermakov, D. Kuziev, A. Babarykin, Acta Montanistica Slovaca, 25:1, 70 (2020) 